\title{
The performance of $1 \%$ solution of baking soda as the mouthwashing for elderly xerostomia patients on the salivary secretion
}

\author{
Ririn Ariyanti*, Sri Tjahajawati*, Marry Siti Mariam* \\ *Department of Oral Biology Faculty of Dentistry Universitas Padjadjaran
}

\begin{abstract}
Introduction: The ageing process in older adults could cause a decreasing salivary secretion. Indicators of salivary secretion could be measured by observing an increasing salivary volume and $\mathrm{pH}$, and a decreasing salivary viscosity. This study was aimed to observe the performance of $1 \%$ solution of baking soda on the salivary secretion of elderly xerostomia patients. Methods: The study used the quasi-experimental method with purposive sampling technique. The subjects were 24 older adults who were administered with $1 \%$ solution of baking soda. Results: The results showed that the averages volume, $\mathrm{pH}$, and viscosity of the saliva before rinsing with $1 \%$ solution of baking soda were lower than after rinsing with the solution $(\mathrm{p}<0.005)$. The average values of volume and $\mathrm{pH}$ of saliva before rinsing of $1 \%$ solution of baking soda were $0.15 \mathrm{ml} / \mathrm{min}$ and 5.4 , respectively, whilst after rinsing with the solution were $0.14 \mathrm{ml} / \mathrm{min}$ and 7.42 , respectively. The difference in saliva viscosity before and after rinsing with the solution showed that there were changes in the viscosity from frothy to watery. Conclusion: $1 \%$ solution of baking soda solution was able to increase the salivary secretion of elderly xerostomia patients, observed from an increasing salivary volume and $\mathrm{pH}$, and a decreasing salivary viscosity after rinsing with $1 \%$ solution of baking soda.
\end{abstract}

Keywords: $1 \%$ solution of baking soda, elderly, saliva secretion

P-ISSN 1979-0201, e-ISSN 2549-6212 Available from:http://jurnal.unpad.ac.id/pjd/article/view/16234

DOI:http://dx.doi.org/10.24198/pjd.vol30no1.16234

Submission: Dec 2017 Publishing: March 2018

\section{INTRODUCTION}

The proportion of older patients in the overall population becomes more significant and the salivary gland dysfunction will become a more prevalent problem in the future 1. It is believed that salivary function decreases as a result of the aging process. $^{2}$ Recent research also attempts to explain the substantial prevalence of older patients with salivary gland dysfunction which is the most common cause of complaints of dry mouth. $^{2}$

Xerostomia is a subjective feeling of oral dryness. Xerostomia is a symptom, not a diagnosis or disease. ${ }^{3}$ Xerostomia is a symptom that should be investigated because it may be indicative of 
an underlying systemic disease, side effects of head and neck radiation, sjögren's syndrome, side effects of medication use, stress, and also age4. While oral dryness is the most commonly result of salivary gland dysfunction, this oral dryness condition may have other causes. ${ }^{3}$ Patients need a careful objective examination to identify the basis of their problem. ${ }^{3}$ Xerostomia is related to the decrease in fluid availability in the oral cavity and the dryness of all oral mucosal surface. ${ }^{5}$

Saliva is a complex fluid produced by the salivary glands. ${ }^{6}$ The decrease in the amount of secreted salivary is the most common symptom of complaints in elderly patients with xerostomia. ${ }^{7}$ This condition is caused by the aging process that affects the changes in the atrophy of the salivary glands. ${ }^{4}$ The systemic diseases suffered and the drugs used for the treatment of systemic diseases also affect the dry mouth condition in the elderly. ${ }^{2}$

Saliva plays an important role in maintaining oral health because it is associated with biological processes that occur in the oral cavity. ${ }^{7}$ Saliva functions in digestion, tasting, regulation of fluid balance, antibacterial, lubrication, buffering, and remineralization. ${ }^{8} \mathrm{~A}$ quantitative decrease of salivary will cause various discomforts in the oral cavity. Individuals who have a reduction in saliva output experience oral dysfunctions, such as difficulties in vocalization, mastication, swallowing, changes in taste, a more susceptible to infection of oral tissue, and increased risk for caries. ${ }^{2,9}$

Composition of saliva determines the function of saliva in protecting tissues in the oral cavity7. Saliva contains numerous inorganic and organic factors. ${ }^{10}$ The primary organic factor is protein. Inorganic factors consist of electrolytes in the form of ions. ${ }^{10}$ One prominent example of salivary electrolyte ions is bicarbonate. ${ }^{10}$

The optimal activity of salivary function is reflected by some physical properties of saliva. The flow rate of saliva determines the $\mathrm{pH}$ and buffer system. The faster the saliva flows, the more the amount of bicarbonate in the saliva that causes the buffer system of saliva to work optimally in maintaining the balance of salivary $\mathrm{pH}^{10}$ Saliva flow rate is associated with the viscosity of saliva. The viscosity of the watery saliva will increase the flow rate of saliva to obtain a good self-cleaning. The high viscosity of the thick saliva causes the attachment of the food to the tooth surface, and the plaque buildup is easy to occur so that it will be classified into calculus. ${ }^{10}$

Decreased salivary secretion can be resolved by stimulating the production of saliva ingredients and salivary substitutes. Treatment of xerostomia may use local and topical methods or systemic medication. ${ }^{9}$ Commonly used ingredients are sugar-free gum or drugs (pilocarpine, cevimeline, anetholetrithione, and amifostine). The side-effects after taking these drugs include an unexpected decrease in salivary $\mathrm{pH}$ in patients with decreased salivary secretions. ${ }^{11}$

The chemicals studied and proven to be effective in inducing salivary production are baking soda. Baking soda is one ingredient that can stimulate the flow of saliva because it contains bicarbonate $\left(\mathrm{NaHCO}_{3}\right)$. The alkaline properties of baking soda increase when it is dissolved in water. ${ }^{12}$ The content of $\mathrm{HCO}_{3}$ - in baking soda solution will react with $\mathrm{H}^{+}$and form $\mathrm{H}_{2} \mathrm{CO}_{3} \cdot{ }^{13} \mathrm{H}_{2} \mathrm{CO}_{3}$ will decompose to $\mathrm{CO}_{2}$ and $\mathrm{H}_{2} \mathrm{O}$ so that when the solution of baking soda is rinsed in the oral cavity, the water content of the oral cavity will increase. ${ }^{13}$

$\mathrm{Na}^{+}$ion content plays a role in the secretion of saliva. ${ }^{13}$ The flavor of baking soda solution will stimulate the parasympathetic nerves of the superior and inferior salivatory nuclei in the brain stem. ${ }^{12}$ This nucleus will be stimulated by the tactile stimulation and tasting of the tongue and the oral and pharyngeal areas enabling an increase in saliva. ${ }^{14}$

\section{METHODS}

This study was conducted by using a solution of baking soda as a mouthwashing solution for elderly xerostomic patients. This type of research is quasiexperimental design. The samples were taken by purposive sampling method from the elderly at Senjarawi, Bunda and Budi Pertiwi Nursing House on September 2016. Six males and eighteen females aged of 60-92 years were included in the study. The ethical clearance was approved by the Health Research Ethics Committee, Faculty of Medicine, Padjadjaran University, Bandung.

Inclusion criteria for subject participation were: (a) xerostomia; (b) had no systemic disease; (c) not taking any nonprescription or prescription medications within the previous 3 months; (d) no 
history of head and neck radiation; (e) asked to remove removable dental prostheses (dentures) for the duration of the study (f) do not have a smoking habit and (g) completion of consent form. ${ }^{5}$

The first phase of this research procedure was the subjects were required to complete and sign the informed consent. Subjects did not eat and drink for at least 30 min before the study. The solution of $1 \%$ baking soda was prepared by dissolving 2.5-gram of baking soda powder into $250 \mathrm{ml}$ aquades. The subjects were asked the following seven questions about oral dryness. ${ }^{5}$

Xerostomia questionnaire ${ }^{5}$ : 1. Are you thirsty? (No/Yes) (Thirst); 2. Are your lips dry? (No/Yes) (Dry Lip); 3. Does the amount of saliva in your mouth seem to be too little (Yes), too much (No), or you don't notice it (No)? (Saliva); 4. Do you have difficulties in swallowing? ( $\mathrm{No} /$ Yes) (Swallow); 5. Do you have any difficulties in speaking? (No/Yes) (Speak); 6. Does your mouth feel dry when eating a meal? (No/Yes) (DryEat); 7. Do you sip liquids to aid in swallowing dry foods? (No/Yes) (SipLiq).

Four of these questions (nos. 3,4,6, and 7) have been correlated with objective findings of salivary gland dysfunction. Three of them (nos. 1, 2 , and 5) were previously used in investigations of dry mouth, and dryness of the lips that successfully predicted salivary gland hypofunction. ${ }^{5}$
The second phase of the experiment was the procedure of collecting saliva. Each subject was asked to rinse with $20 \mathrm{ml}$ of aquades for 30 seconds without swallowing. The position of the body was sitting upright and relaxed while collecting saliva in the oral cavity for 5 minutes. Every minute, the subject was asked to spit the saliva into the saliva storage container (spitting method). ${ }^{15}$

The collected saliva was used for measuring the volume, $\mathrm{pH}$, and viscosity. The $\mathrm{pH}$ of saliva was measured using universal indicator $\mathrm{pH}$ 0-14. The viscosity of saliva was measured qualitatively by the dental mirror. The data obtained were salivary secretions before and after rinsing with $1 \%$ solution of baking soda in the elderly who suffered xerostomia. The normality and differential tests were conducted by using Shapiro-Wilk and Wilcoxon respectively.

\section{RESULTS}

The results of this study were the values of salivary secretion by observing the increase in the volume and $\mathrm{pH}$ of saliva and the decrease in viscosity of saliva, before and after rinsing with $1 \%$ solution of baking soda. The data obtained were then tested for the normality using Saphiro Wilk.

Table 1 showed the average values of volume and $\mathrm{pH}$ of saliva before rinsing with $1 \%$

Table 1. Mean, Std. Deviation, Min, Max, Shapiro-Wilk, Wilcoxon volume and pH of saliva before and after rinsing with $1 \%$ solution of baking soda in the elderlies who suffer xerostomia in Senjarawi, Asuhan Bunda, Budi Pertiwi Nursing Homes Bandung, Indonesia.

\begin{tabular}{|c|c|c|c|c|c|c|c|c|c|}
\hline \multirow{2}{*}{ Variable } & \multirow{2}{*}{$\mathbf{N}$} & \multirow{2}{*}{$\begin{array}{c}\text { Mean } \\
(\mathrm{ml})\end{array}$} & \multirow{2}{*}{$\begin{array}{c}\text { Std. } \\
\text { Deviation }\end{array}$} & \multirow{2}{*}{ Min } & \multirow{2}{*}{$\operatorname{Max}$} & \multicolumn{2}{|c|}{ Shapiro-Wilk } & \multicolumn{2}{|c|}{ Wilcoxon } \\
\hline & & & & & & Statistic & Sig & Z & $\mathrm{p}$-value \\
\hline $\begin{array}{l}\text { Volume of saliva before rinsing } \\
\text { of } 1 \% \text { baking soda solution }\end{array}$ & 24 & ,1483 & , 08976 & , 10 & ,40 & ,714 & ,000 & \multirow[b]{2}{*}{$-4,293^{b}$} & \multirow[b]{2}{*}{, 000} \\
\hline $\begin{array}{l}\text { Volume of saliva after rinsing } \\
\text { of } 1 \% \text { baking soda solution }\end{array}$ & 24 & ,4117 & 09985 & ,28 &, 62 & ,924 & ,071 & & \\
\hline $\begin{array}{l}\mathrm{pH} \text { of saliva before rinsing of } \\
1 \% \text { baking soda solution }\end{array}$ & 24 & 5,4167 & ,50361 & 5,00 & 6,00 & ,629 & ,000 & \multirow{2}{*}{$-4,610^{\mathrm{b}}$} & \multirow{2}{*}{,000 } \\
\hline $\begin{array}{l}\mathrm{pH} \text { of saliva after rinsing of } 1 \% \\
\text { baking soda solution }\end{array}$ & 24 & 7,4167 & 65386 & 6,00 & 8,00 & ,752 & ,000 & & \\
\hline
\end{tabular}

Table 2. The viscosity of saliva before and after rinsing with $1 \%$ solution of baking soda in the elderlies who suffer xerostomia in Senjarawi, Asuhan Bunda, Budi Pertiwi Nursing Homes Bandung, Indonesia.

\begin{tabular}{|c|c|c|}
\hline Variable & $\begin{array}{c}\text { Viscosity of saliva before rinsing } 1 \% \text { Baking Soda } \\
\text { solution }\end{array}$ & $\begin{array}{c}\text { Viscosity of saliva after rising } 1 \% \text { baking soda } \\
\text { solution }\end{array}$ \\
\hline Saliva secretion & Frothy & Watery \\
\hline
\end{tabular}


solution of baking soda were $0.15 \mathrm{ml} / \mathrm{min}$ and 5.4 , respectively, while after rinsing with the solution the values were $0.14 \mathrm{ml} / \mathrm{min}$ and 7.42 , respectively. Table 2 showed the differences in viscosity of saliva before and after rinsing with the solution, showing changes in the viscosity of frothy to a watery

\section{DISCUSSION}

The elderlies at the Senjarawi, Asuhan Bunda and Budi Pertiwi nursing home who were the subjects of this study were determined based on the population criteria supported by the questionnaire filling through the interview process. Most of the elderlies did not complain about the subjective dryness of the mouth, but the results of interviews on the filling questionnaire showed that the elderlies had xerostomia. Elderlies in the subjects of this study belonged to a group that was still active and had no history of certain systemic diseases that affected the salivary secretion.

This research used $1 \%$ solution of baking soda containing bicarbonate with chemical formula of $\mathrm{NaHCO}_{3}$. The content is a substance that can increase the volume and $\mathrm{pH}$ of saliva and decrease the viscosity of saliva based on the chemical properties of baking soda. ${ }^{12}$ Table 1 shows a difference in mean salivary volume in elderly xerostomia patients before and after rinsing with $1 \%$ solution of baking soda. The average volume of saliva of elderly xerostomia patients before rinsing the $1 \%$ solution of baking soda was below normal. The normal conditions without stimulation showed the mean volume of saliva was $0.3-0.5 \mathrm{ml} / \mathrm{min}$ as elderly xerostomia patients had decreased salivary secretions due to the aging process, characterized by the changes of inlining in intermediate ductus cells that had atrophy in the salivary glands and disappearance of parenchyma glands replaced by fatty tissue. ${ }^{4}$

However, the average volume of saliva of elderly xerostomia patients after rinsing with $1 \%$ solution of baking soda were back to normal conditions. The mean value of the volume of saliva of elderly xerostomia patients increased through mechanical stimulation of the gargle movement causing the operation of the chewing muscles that were eventually stimulating the salivary glands. ${ }^{10}$ Taste of $1 \%$ solution of baking soda will stimulate the parasympathetic nerve from the superior and inferior salivatory nucleus of the brain stem. This nucleus will be boosted by tactile stimulation and tasting of the tongue and the oral and pharyngeal areas, resulting in increased salivary secretion ${ }^{14}$. The increased volume of saliva provides moisture, lubrication, and can resolve xerostomia complaints due to the decreased salivary secretion in the elderly. ${ }^{10}$

Table 1 shows an average difference between $\mathrm{pH}$ of saliva in elderly xerostomia patients before and after rinsing with $1 \%$ solution of baking soda. The $\mathrm{pH}$ of saliva before rinsing with $1 \%$ solution of baking soda indicated the condition of the oral cavity was acid while the $\mathrm{pH}$ of saliva after rinsing of $1 \%$ solution of baking soda indicated oral cavity conditions at a normal $\mathrm{pH}$. Increased $\mathrm{pH}$ of saliva after rinsing with $1 \%$ solution of baking soda demonstrates that baking soda is alkaline. ${ }^{16}$

Table 2 shows that the viscosity of saliva changes before and after rinsing with $1 \%$ solution of baking soda. Viscosity describes the consistency of a liquid in the oral cavity. The results of this study showed that the viscosity of saliva before rinsing of $1 \%$ solution of baking soda was frothy, and viscosity of saliva after rinsing of $1 \%$ solution of baking soda was watery.

The data show a decrease of salivary viscosity after rinsing with $1 \%$ solution of baking soda becoming more watery. This change is caused by a mechanical stimulation through gargling movement that will stimulate salivary glands, especially parotid gland consists of asini cells, to produce dilute secretions. ${ }^{17}$ The decreased viscosity after rinsing with $1 \%$ solution of baking soda in elderly xerostomia patients is in accordance with Turner's (1978) statement that $1 \%$ solution of baking soda can be used to reduce mucus so that it can be used as a nasal and throat rinse. ${ }^{18}$

Based on the results of the Wilcoxon difference test the null hypothesis is rejected and the one hypothesis is accepted. This means that there are statistically significant differences in the volume and $\mathrm{pH}$ of saliva before and after rinsing with $1 \%$ solution of baking soda in elderly xerostomic patients. Similarly, the viscosity of saliva study result before and after rinsing with $1 \%$ solution of baking soda were performed visually, showed a difference of a more watery after rinsing of $1 \%$ solution of baking soda. 


\section{CONCLUSION}

The higher level of the Phaleria macrocarpa leaves extract concentration, the higher inhibition zone diameter against Candida albicans, with the highest in concentration $80 \%$.

\section{REFERENCES}

1. Kemenkes RI. Buletin jendela data dan informasi kesehtan: Gambaran kesehatan lanjut usia di indonesia: pusat data informasi kemenkes RI. [homepage internet] Jakarta: Kementrian Kesehatan RI. 2013. p. 1-4. [cited 4 Januari 2014] [About 40 screens]. Available From: http//depkes.go.id.

2. Gupta A, Epstein JB, Sroussi H. Hyposalivation in elderly patients. J Can Dent Assoc. 2006 Jan;72(9):841-6. AvailableFrom: https: / /www. cda-adc.ca/jadc/vol-72/issue-9/841.html.

3. Greenberg MS, Glick $M$. Oral medicine: diagnosis and treatment. $10^{\text {th }}$ Ed. Spain: BC Decker.; 2003. P. 236, 259-60.

4. Hasibuan S. Keluhan mulut kering ditinjau dari faktor penyebab manifestasi dan penanggulangannya. [minor thesis] Sumatera Utara : USU Library Lectures Papers; 2002. p. 1-7. Avaliable From: Available http://library. usu.ac.id.

5. Ship JA, Fischer DJ. The relationship between dehydration and parotid salivary gland function in young and older healthy adults. $J$ Gerontol A Biol Sci Med Sci. 1997;52(5)310-19. Available From: https://www.ncbi.nlm.nih. gov/pubmed/9310086.

6. Chandra S, Chandra S. Chandra M. Chandra G, Chandra N. $2^{\text {th }}$ Ed. Textbook of dental \& oral histology with embriology \& MCQs. New Delhi: JAYPEE. (P) LTD. 2010 Avaliable From: https://www.amazon.com/Textbook-DentalOral-Histology-Embryology/dp/8184487126.

7. Nanci A. Ten cate's oral histology: development, structure and fucntion. $6^{\text {th }}$ ed. USA: Mosby. 2003. Avalaiable From: https:// www.amazon.com/Ten-Cates-Oral-HistologyDevelopment/dp/0323016146.

8. Rensburg JV, BG. Biology. $1^{\text {st }}$ Ed. Berlin: Quintessence Publishing. 1995. p. 45979. Avaliable From: https://www.amazon. com/Oral-Biology-Jensen-Van-Rensburg/ $\mathrm{dp} / 0867152710$.

9. Stipetic MM. Xerostomia-Diagnosis and treatment. Med Scie 2012 Aug-Sep.; Rad. 514 38(2012):69-91. Avaliable From: file:///C:/ Users/user/Downloads/Rad_514_med_ znanosti_8.pdf.

10. Amerongen A, Rafiah VNA. Ludah dan kelenjar ludah arti bagi kesehatan gigi. Yogyakarta: Gajah Mada University Press. 1991. p. 261269. Avaliable From: http://digilib.usu.ac.id/ buku/2303/Ludah-dan-kelenjar-ludah-artibagi-kesehatan-gigi.html.

11. Kidd EAM , Joyston BS. Dasar-dasar karies, penyakit dan penanggulangannya. Jakarta: CV EGC. 1992. p. 213-218. Avaliable From: http:// digilib.usu.ac.id/buku/29738/Dasar-dasarkaries-penyakit-dan-penanggulangannya(essentials-of-dental-caries).html.

12. Anggraeni D, Tjahajawati S, Wihardja R. Saliva secretion difference before and after rinsing with baking soda on menopause women. Pad J Dent. 2007;19(1):28-33. DOI: 10.24198/pjd. vol19no1.14178 Avaliable From: http: / / jurnal. unpad.ac.id/pjd/article/view/14178/6856.

13. Choi SE, Kim HS. Sodium bicarbonate solution versus chlorhexidine mouthwash in oral care of acute leukimia patients undergoing induction chemotheraphy: a randomized controlled trial. Asian Nurs Res (Korean Soc Nurs Sci). 2012 Jun;6(2):60-6. DOI: 10.1016/j. anr.2012.05.004. Epub 2012 May 24. Avaliable From: https://www.ncbi.nlm.nih.gov/ pubmed/25030829.

14. Guyton AC. Hall JE. Buku ajar fisiologi kedokteran. 11 $11^{\text {th }}$ ed. Jakarta: EGC. 2007. p. 835-836. Avaliable From: http://library. poltekkespalembang.ac.id/keplinggau/index. php?p=show_detail\&id=955.

15. Dawes $C$. Physiological factor affecting salivary flow rate, oral sugar clarance and sensation of dry mouthin man. J Den Res. 1987 Feb;66: 648-53. DOI: 10.1177/00220345870660S107 Avaliable from: https://www.ncbi.nlm.nih. gov/pubmed/3476629.

16. ASHP, Gerald K, McEvoy. American hospital formulary service drug information essentials 2004-2005. $8^{\text {th }}$ ed. American: Goodreads. 2000. p. 1520. Avaliable From: https:// www.goodreads.com/author/list/631111. Gerald_K_McEvoy. 
17. Eroschenko VP. Atlas Histologi di fiore dengan korelasi fungsional. $9^{\text {th }}$ ed. Jakarta: EGC. 2003. p. 162-71. Avaliable From: https://www. belbuk.com/atlas-histologi-di-fiore-dengan- korelasi-fungsional-edisi-9-p-3622.html.

18. Turner P, Balmford JE, Becket AH. Drug and pharmaceutical adjuvants. London: The Pharmaceutical Press. 1978. p. 444. 